\title{
Chlorinated Hydrocarbons in Eels (Anguilla anguilla $L$.) from the River Rhine
}

\author{
R. Vecsei-Hohl, L. Gourec and M. Bruna \\ Zentrum für Umweltforschung der Universität des Saarlandes, \\ W-6602 Saarbrücken-Dudwiler, FRG \\ M. Zeh and K. Fent \\ Swiss Federal Institute for Water Resources and Water Pollution Control \\ (EAWAG/ETH), CH-6047 Kastanienbaum, Switzerland
}

Polychlorinated biphenyls (PCBs) and other chlorinated hydrocarbons were detected in the environment only long after the onset of their production. Due to their high persistence and widespread distribution, PCBs, DDT, and their metabolites can be detected in different environmental compartments even after production has ceased [1]. Through bioaccumulation and bioconcentration residues are found in body lipids and organs of fish [2-4], and animals at high trophic levels (e.g., fisheating mammals such as otters) are thought to be negatively affected [5].

In this paper we report on the concentrations of selected chlorinated hydrocarbons in eels from the High Rhine. In earlier quantitative analyses, either only the total PCB concentration was determined without reporting on individual congeners $[6,7]$, or only little data have been reported on particular sites [8]. As the congeners show different physical, chemical, and toxicological characteristics depending on their degree of chlorination and structure congener-specific data are needed. Here, concentrations of some selected PCB congeners are given and compared with data from 1984 [8] to detect trends. The results indicate a still considerable degree of contamination.

Nineteen eels were caught near the hydroelectric power plant RheinsfeldenEglisau, Switzerland (Fig. 1). Ten eels were caught along the right bank of the river, and nine along the left bank, below the mouth of the River Glatt. This river, flowing through the urban agglomeration of Zurich, is polluted by contaminants of anthropogenic origin. The fish were caught by electroshocking on May 14, 1990, and transported live in an oxygenated container to Saarbrücken, FRG. A filet of about $8 \mathrm{~cm}$ long was cut from each fish around the base of the dorsal fin for residue analyses performed at the Zentrum für Umweltforschung (Universität des Saarlandes).

The following substances were determined: $\alpha$ - and $\beta$-hexachlorocyclohexane $(\mathrm{HCH})$, lindane, dieldrin, hexachlorobenzene (HCB), DDT and its metabolites DDE and DDD, PCB con-

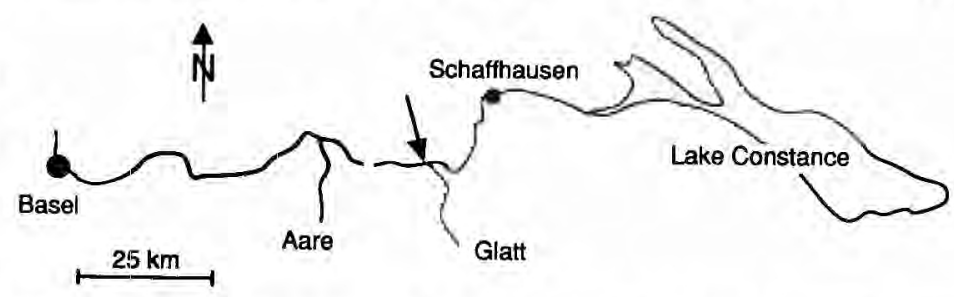

Fig. 1. The High Rhine between Lake Constance and Basel. The sampling site near Eglisau, Switzerland, just below the mouth of the River Glatt, is marked by an arrow 
geners 28 (trichlorobiphenyl), 52 (tetbiphenyl), 138 and 153 (hexachlorobiphenyls), and 180 (heptachlorobiphenyl) as defined by Ballschmitter and Zell [9] and IUPAC. The analytical procedure employing capillary gas chromatography was used as described in [10].

The concentrations measured are given in Table 1 and Fig. 2 and are compared to statuatory German [11] and Swiss [12] maximum allowable concentrations (MAC). Concentrations of $\mathrm{HCH}$ and HCB are near the detection limit in all 19 eels, and by a factor 5 to 200 below the MAC values (Fig. 2). $\beta$-HCH values always exceed those of $\alpha-\mathrm{HCH}$. Dieldrin and lindane were detected in rachlorobiphenyl), 101 (pentachloro-

small quantities: 0.002 to $0.040 \mathrm{mg} / \mathrm{kg}$ for dieldrin and 0.003 to $0.040 \mathrm{mg} / \mathrm{kg}$ for lindane, both being clearly below MAC values of 1.0 and $2.0 \mathrm{mg} / \mathrm{kg}$, respectively. Whereas residues of $\mathrm{HCH}$ are similar, HCB residues are lower than those reported for eels in the Upper and High Rhine during 1976-1981 [7].

Table 1 gives average concentrations of DDT and its metabolites, individual PCB congeners and total PCB content of the 19 eels that were divided into three size groups. Contents of DDT and its metabolites ( $\Sigma$ DDT) between individual fish range between 0.065 and $0.750 \mathrm{mg} / \mathrm{kg}$ and remain clearly below the German MAC value of $3.5 \mathrm{mg} / \mathrm{kg}$. Eels of the size group $50.5-81.5 \mathrm{~cm}$

Table 1. Concentrations of selected PCBs and chlorinated hydrocarbons (in $\mathrm{mg} / \mathrm{kg}$ wet weight), biometric data, and maximum allowable concentration (MAC) values $[11,12]$ for three size groups of eels

\begin{tabular}{|c|c|c|c|c|c|c|c|c|c|}
\hline \multirow{2}{*}{$\begin{array}{l}\text { Length }[\mathrm{cm}] \\
\text { Substance }\end{array}$} & \multicolumn{2}{|c|}{$32.0-40.0$} & \multicolumn{2}{|c|}{$40.5-50.0$} & \multicolumn{2}{|c|}{$50.5-81.5$} & \multirow{2}{*}{$\begin{array}{l}\text { MAC- } \\
\text { value }\end{array}$} & \multirow[b]{2}{*}{$\mathrm{CH}$} & \\
\hline & & SD & $\overline{\mathbf{x}}$ & SD & & SD & & & \\
\hline DDE & 0.101 & 0.071 & 0.117 & 0.06 & 0.215 & 0.124 & & & \\
\hline DDD & 0.016 & 0.004 & 0.036 & 0.029 & 0.093 & 0.064 & & & \\
\hline DDT & 0.039 & 0.028 & 0.063 & 0.053 & 0.093 & 0.049 & & & \\
\hline$\Sigma$ DDT & 0.156 & 0.097 & 0.217 & 0.131 & 0.407 & 0.241 & 3.5 & & \\
\hline PCB 52 & 0,007 & 0.004 & 0.014 & 0.012 & 0.030 & 0.019 & 0.2 & & \\
\hline PCB 101 & 0.022 & 0.013 & 0.043 & 0.027 & 0.051 & 0.031 & 0.2 & & \\
\hline PCB 138 & 0.163 & 0.1 & 0.179 & 0.088 & 0.325 & 0.183 & 0.3 & & \\
\hline РCB 153 & 0.169 & 0.095 & 0.183 & 0.089 & 0.294 & 0.172 & 0.3 & & \\
\hline PCB 180 & 0.088 & 0.079 & 0.084 & 0.05 & 0.148 & 0.095 & 0.2 & & \\
\hline \multirow[t]{5}{*}{$\Sigma$ PCB } & 1.59 & 1.05 & 1.68 & 0.83 & 2.85 & 1.65 & & 1.0 & \\
\hline & 4.20 & 2.11 & 6.86 & 3.82 & 14.07 & 8.46 & & & \\
\hline & 70.3 & 18.2 & 154.1 & 18.8 & 509.3 & 293.4 & & & \\
\hline & 36.6 & 2.6 & 46.4 & 1.5 & 63.5 & 10.6 & & & \\
\hline & 7 & & 6 & & & & & & \\
\hline
\end{tabular}

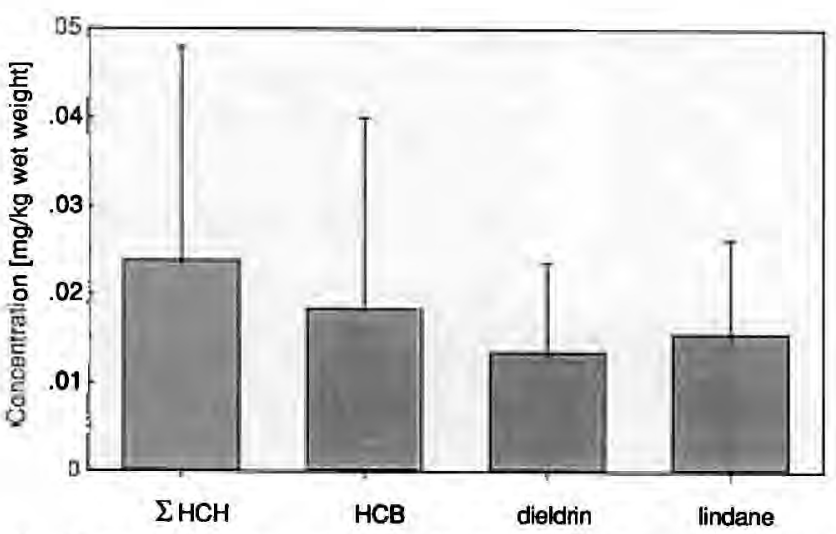

Fig. 2. Average concentrations $\pm \mathrm{SD}(n=19)$ of hexachlorocyclohexane $(\mathrm{HCH}$, sum of $\alpha$ and $\beta-\mathrm{HCH}$ ), hexachlorobenzene (HCB), dieldrin, and lindane. Measured concentrations are partly near the detection limit $(0.005 \mathrm{mg} / \mathrm{kg}$ wet weight) show a significantly higher concentration (ANOVA, Fisher PLSD test, $p<$ 0.05 ) of $\Sigma$ DDT than those belonging to the size group $32-40 \mathrm{~cm}$. Eel DDT residues ( $\Sigma$ DDT) tend to be slightly lower than 1976-1981 [7].

Of the PCB congeners congeners 52, $101,138,153$, and 180 were quantified, whereas congener 28 could not be detected. The hexachlorobiphenyls 138 and 153 show the highest concentrations, but heptachlorobiphenyl 180 is also abundant (Table 1). The concentrations of the congeners 101 and 52 are markedly lower. The total PCB content was estimated with congeners 138,153 , and 180 using the formula given in [13]. The total PCB content between individual fish varies between 0.58 and 5.30 $\mathrm{mg} / \mathrm{kg}$ wet weight. The data also in dicate a tendency towards higher concentrations in larger (older) fish for congeners 52,101, and 138, however, this cannot be proved statistically (Fig. 3). Also, no significant, positive correlation could be found between total PCB and fat content (ANOVA). The two longest and heaviest eels show high values ( $\Sigma$ PCB 5.3 and 4.6 $\mathrm{mg} / \mathrm{kg}$ ). The Swiss MAC value for $\Sigma$ PCB $(1.0 \mathrm{mg} / \mathrm{kg}$ for the edible part of fish) was exceeded in all but four eels. Notably, all fish that had reached the legal catching size of $50 \mathrm{~cm}$ exceeded the Swiss MAC value (Fig. 3). Five eels exceeded the German MAC value for PCB 138 and 153, three fish the value for congener 180 . No difference was found in the PCB and pesticide contamination of eels caught on the right or left bank of the Rhine.

Comparison of the present PCB data with those of previous studies on fish from the River Rhine $[6,7]$ is hindered because different sample treatment and analytical methods were employed. However, they can be compared with those given in [8] and those of Krüger and Kruse [14] who used the same analytical procedures. Eels from the River Rhine and its tributaries were reported in 1984 to contain PCB residues (individual congeners and total $\mathrm{PCB}$ ) only slightly higher than those determined here [8]. Table 2 shows that the DDE and DDD contamination in eels from the High Rhine is higher than in other rivers except for eels from the Elbe at Lauenburg which were more contaminated [14]. Also, average contents of $P C B$ congeners 138,153 , and 180 in 


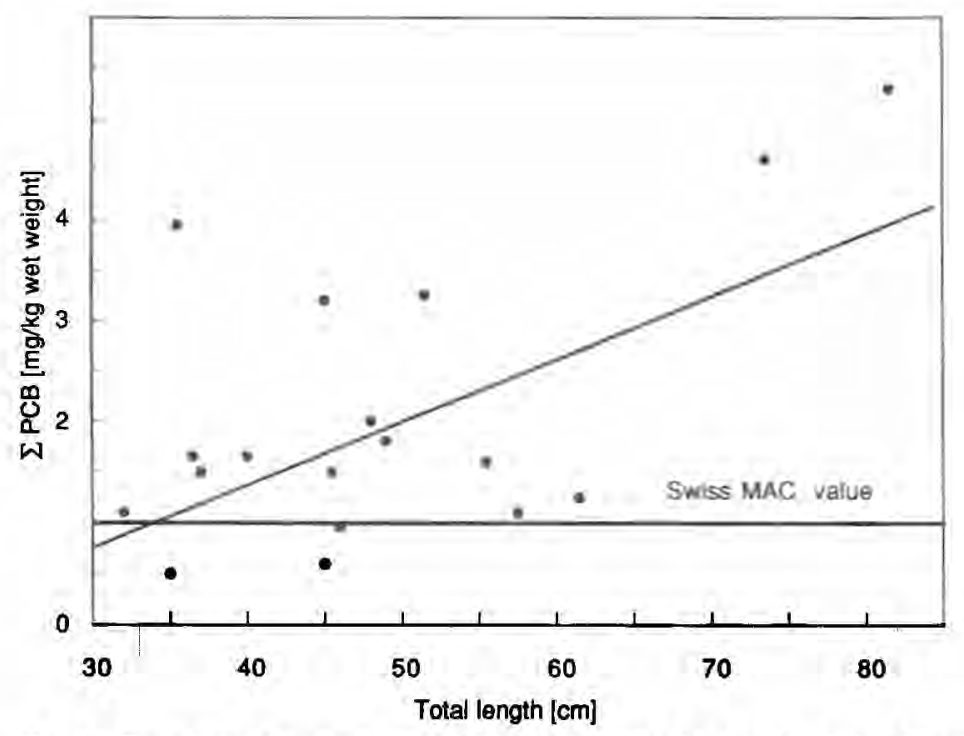

Fig. 3. Correlation between total PCB content and fish length. Eels of similar length show considerable differences in contamination. Regression: $y=0.063 x-1.014, r^{2}=0.356$

Table 2. Comparison with data from [14], using the same analytical methods. Concentration in $\mathrm{mg} / \mathrm{kg}$ wet weight $(\mathrm{n} . \mathrm{d}$. = not detected)

\begin{tabular}{llllllll}
\hline & $\begin{array}{l}\text { High } \\
\text { Rhine } \\
\text { (present } \\
\text { study) }\end{array}$ & $\begin{array}{l}\text { Elbe } \\
\text { (Lauen- } \\
\text { burg) }\end{array}$ & $\begin{array}{l}\text { Ems } \\
\text { (Meppen) }\end{array}$ & $\begin{array}{l}\text { Hase } \\
\text { (Meppen) }\end{array}$ & $\begin{array}{l}\text { Aller } \\
\text { (Gifhorn) }\end{array}$ & $\begin{array}{l}\text { Lutter } \\
\text { (Sïdheide) }\end{array}$ & $\begin{array}{l}\text { Dümmer } \\
\text { Lake }\end{array}$ \\
\hline$n$ & 19 & 11 & 11 & 15 & 6 & 9 & 19 \\
Length & & & & & & & \\
[cm] & 48.2 & 49.9 & 32.8 & 32.8 & 47.5 & 48.2 & 45.8 \\
Weight [g] & 235.4 & 259.0 & 60.9 & 63.4 & 215.0 & 218.0 & 166.0 \\
Fat [\%] & 8.2 & 9.9 & 12.2 & 15.1 & 14.1 & 9.1 & 8.2 \\
$\alpha$-HCH & 0.004 & 0.047 & 0.005 & 0.007 & 0.003 & 0.003 & 0.002 \\
HCB & 0.004 & 0.344 & 0.037 & 0.011 & 0.007 & 0.009 & 0.003 \\
Lindane & 0.016 & 0.066 & 0.109 & 0.032 & 0.013 & 0.006 & 0.005 \\
DDE & 0.142 & 0.155 & 0.091 & 0.040 & 0.061 & 0.035 & 0.013 \\
DDD & 0.048 & 0.202 & 0.036 & 0.017 & 0.030 & 0.022 & 0.009 \\
PCB 28 & n.d. & n.d. & 0.025 & 0.011 & 0.004 & 0.003 & n.d. \\
PCB 52 & 0.016 & 0.020 & 0.060 & 0.018 & 0.070 & 0.006 & 0.002 \\
PCB 101 & 0.038 & 0.030 & 0.037 & 0.017 & 0.094 & 0.006 & 0.004 \\
PCB 138 & 0.219 & 0.061 & 0.160 & 0.095 & 0.152 & 0.031 & 0.021 \\
PCB 153 & 0.213 & 0.065 & 0.156 & 0.099 & 0.186 & 0.042 & 0.026 \\
PCB 180 & 0.106 & 0.029 & 0.062 & 0.042 & 0.061 & 0.020 & 0.013 \\
\hline
\end{tabular}

eels from the High Rhine were reached by no other group.

This study shows that higher residue concentrations occur for higher chlorinated PCB congeners (in particular congeners 138 and 153) than for less chlorinated congeners, similar to data reported for eels in 1984 [8]. Congener 28 could not be detected at all. A similar distribution of congeners was found in salmonids of Lake Ontario (Canada). There, congener 153 occurred in highest concentrations, and several sites in the USA, Canada, Europe, and the Antarctic [15]. In the blood of fish consumers from Wisconsin (USA), the congeners 118,138 , 153 , and 180 were most frequent [16], and in human adipose tissue the congeners $99,138,153,170$, and 180 dominated [17]. Coplanar PCBs (congeners $77,126,169)$ are generally the most toxic congeners, followed by the monoortho analogs and the di-ortho analogs of the coplanar PCBs [18]. Breams (Abramis brama L.) from the River Saar near Völklingen, FRG, showed a different distribution in that less chlorinated PCBs dominated [14]. This was probably caused by the application of PCBs with a low boiling temperature in the mining industry. However, other PCB sources account for the fish residues at the sampling site in the River High Rhine.

The present study shows that the PCB contamination of eels in the River Rhine can still be significant (highest measured value $5.3 \mathrm{mg}$ total $\mathrm{PCB} / \mathrm{kg}$ wet weight). Further studies using larger sample sizes and standard analytical methods are needed to further substantiate concentrations and distribution of the different PCB congeners in other fish species. In particular, emphasis should be placed on the quantification of the highly toxic coplanar congeners, rather than only estimating total PCB levels.

We thank K. E. Krüger (Universität des Saarlandes) for help with the analysis, and W. Giger (EAWAG) for reading the manuscript.

Received November 18, 1991 and March 9. 1992

1. Hansen, L. G., in: Polychlorinated Biphenyls (PCBs): Mammalian and Environmental Toxicology, p. 15 (Safe, S., ed.). Berlin: Springer 1987

2. Swackhamer, D. L., Hites, R. A.: Environ. Sci. Technol. 22, 543 (1988)

3. Niimi, A. J., Oliver, B. G.: ibid. 23, 83 (1989)

4. Oliver, B. G., Niimi, A. J.: ibid. 22, 388 (1988)

5. Weber, D.: PCBs als Ursache des Fischotterrückganges in Europa und in der Schweiz: Hypothesen, Fakten, fehlende Grundlagen. Dokumentation im Auftrag des Bundesamtes für Umwelt, Wald und Landschaft. Reinach: Hintermann \& Weber AG 1990 
6. Schweizer, C., Tarradellas, J.: Chimia 34,509 (1980)

7. Binneman, P. H., Sandmeyer, U., Schmuck, E.: Z. Lebensm. Unters. Forsch. 176, 253 (1983)

8. Deutsche Forschungsgemeinschaft: Polychlorierte Biphenyle. Bestandesaufnahme über Analytik, Vorkommen, $\mathrm{Ki}$ netik und Toxikologie. Mitteilung XIII der Senatskommission zur Prüfung von Rückständen in Lebensmitteln, p. 42. Weinheim: VCH Verlagsgesellschaft 1988

9. Ballschmitter, K., Zell, M.: Fresenius Z. Anal. Chem. 302, 20 (1980)

10. Bundesgesundheitsblatt BRD Nr. 18: Untersuchungsmethoden zur Bestimmung der Rückstände von Chlorkohlenwasserstoff-Pestiziden in oder auf Le- bensmitteln tierischer Herkunft, 269 (1974); Bundesgesundheitsblatt BRD Nr. 281: Analyseverfahren zur Bestimmung von ausgewählten PCB-Einzelkomponenten in Lebensmitteln (1985)

11. Deutsche Pflanzenschutzmittel-Höchstmengenverordnung (PHmV): Bundesgesetzblatt Teil I, Anlage 1 und 2, 1864 (1989); Deutsche Schadstoff-Höchstmengenverordnung (SHmV): Bundesgesetzblatt Teil I, 422 (1988)

12. Verordnung über Fremd- und Inhaltsstoffe in Lebensmitteln (FIV): Verordnung Nr. 817.022, EDI, Bern (1990)

13. VDLUVA: Rahmenkonzept für die Routineanalytik von polychlorierten Biphenylen (PCB). VDLUVA-Schriftenreihe, Heft 12, Karlsruhe 1984

14. Krüger, K. E., Kruse, R.: Ermittlung der optimalen Parameter bei der Auswahl von Fischen für die Umweltprobenbank. Abschlußbericht zum F+EVorhaben 10605052 des Umweltbundesamtes, Berlin 1988

15. Jones, K.: Sci. Tot. Environ. 68, 141 (1988)

16. Sonzogni, W., et al.: Arch. Environ. Contam. Toxicol. 20, 56 (1991)

17. Focardi, S., Romei, R.: Chemosphere 16, 2315 (1987)

18. Parkinson, A., Safe, S., in: Polychlorinated Biphenyls (PCBs): Mammalian and Environmental Toxicology, p. 49 (Safe, S., ed.). Berlin: Springer 1987 